\title{
Perencanaan kawasan karst sebagai kawasan geowisata di Kabupaten Grobogan, Jawa Tengah
}

\author{
Reisya Rahmaํㅜ Lury Sevita Yusiana ${ }^{1 *}$, I Gusti Alit Gunadi²
}

1. Prodi Arsitektur Pertamanan, Fakultas Pertanian, Universitas Udayana, Denpasar, Indonesia 80232

2. Prodi Agroekoteknologi, Fakultas Pertanian, Universitas Udayana, Denpasar, Indonesia 80232

*E-mail: lury.yusiana@unud.ac.id

\begin{abstract}
The Karst Area Planning as an Area Geotourism in Grobogan Regency of Central Java. The karst area in Grobogan Regency is a geological protected area that includes the Sukolilo Karst Landscape Area. The karst area has a lot of potential that can be used as a tourist attraction. The karst area requires a plan in suitable with the potential and constraints. The planning can be done by developing the karst area as a geotourism. This research method uses survey methods which stages are inventary, analysis, synthesis, concepts, and planning. In the assessment analysis of the 12 attractions there are 4 (four) that have high potential to be developed i.e. Lawa and Macan Caves, Gulingan Waterfall, Lamping Hill and Widuri Waterfall. The basic concept of this planning uses the concept of geotourism as a special interest tour developed into a spatial plan, activity plan and facility plan. The final result of this planning are the site plan of attraction Lawa and Macan Caves, Waterfall Gulingan, Lamping Hill and Widuri Waterfall as a Geotourism that is implemented in the karst of Grobogan Regency
\end{abstract}

Keywords: attraction, geotourism, karst, planning

\section{Pendahuluan}

Kawasan Karst adalah bentuk kawasan khas yang terjadi akibat proses pelarutan pada suatu kawasan batuan karbonat atau batuan mudah terlarut seperti batu gamping sehingga menghasilkan permukaan bumi yang unik dan menarik (Kementerian ESDM, 2012). Hasil pelarutan tersebut membentuk bukit-bukit kapur, munculnya mata air pada rekahan batuan, dan mengalirnya sungai-sungai bawah tanah dengan lorong gua. Kawasan karst mempunyai banyak potensi dari eksokarst (bagian karst yang berada di atas permukaan bumi) dan endokarst (bagian karst yang berada di bawah permukaan bumi). Selain itu, juga mempunyai fungsi sebagai penyimpan cadangan air terbesar bagi wilayah di sekitarnya.

Kabupaten Grobogan merupakan salah satu kabupaten di Provinsi Jawa Tengah yang memiliki bentang alam karst. Bentang alam karst di Kabupaten Grobogan merupakan satu kesatuan dengan bentang alam karst di Kawasan Bentang Alam Karst Sukolilo (KBAK Sukolilo) yang telah ditetapkan sebagai kawasan lindung (Kementerian ESDM, 2014). Kawasan karst di Kabupaten Grobogan memiliki 81 mata air yang berpotensi sebagai sumberdaya air dan memiliki 38 gua air yang tersebar di kawasan karst (BLH, 2014). Namun, kawasan karst juga merupakan kawasan yang memiliki resiko kerusakan yang tinggi pada lingkungannya. Dengan adanya potensi dan kendala tersebut maka kawasan ini memerlukan adanya perlindungan, namun juga tetap dapat diupayakan pengelolaan yang menguntungkan selama kegiatan yang dilakukan sesuai dengan potensi dan kondisi kawasan tersebut. Salah satu cara yang dapat diupayakan dalam pengelolaan kawasan karst yang berwawasan konservasi adalah dengan pengembangan geowisata.

\section{Metode}

Penelitian dilakukan di kawasan karst Kabupaten Grobogan, Jawa Tengah dengan luas $\pm 112,20 \mathrm{~km}^{2}$ dan berada pada ketinggian antara 100-500 mdpl. Peta lokasi penelitian dapat dilihat pada Gambar 1. Penelitian ini dimulai dari Bulan Agustus 2018 hingga Desember 2018. Alat yang digunakan adalah kamera digital, alat tulis, Microsoft Office Word, Google Earth, ArcGIS, dan Photoshop. Bahan yang digunakan adalah peta bentang alam karst Kendeng Utara, dan peta wilayah Kabupaten Grobogan. 


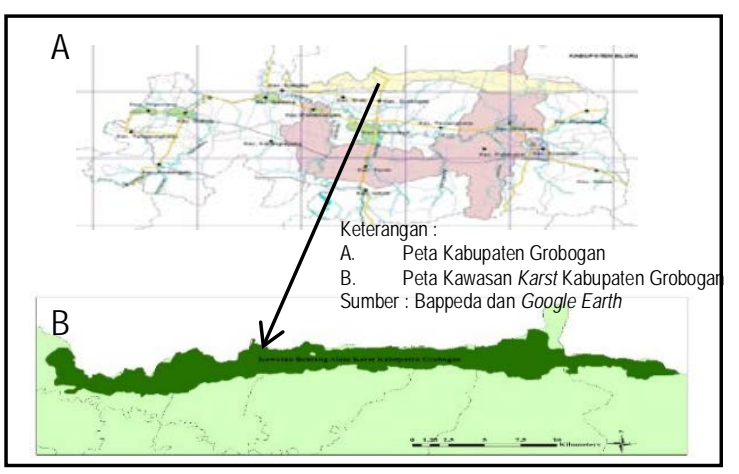

Gambar 1. Peta Lokasi Penelitian

Metode pengumpulan data yang digunakan dalam penelitian ini berupa metode survei dan metode studi pustaka. Metode survei terdiri dari observasi, wawancara dan kuisioner. Metode ini digunakan untuk mengumpulkan data mengenai kondisi biofisik dan masyarakat di sekitar kawasan karst.

Tahapan yang dilakukan dalam penelitian ini terdiri atas inventarisasi, analisis dan sintesis, konsep dan perencanaan. Tahapan inventarisasi dilakukan dengan melihat kondisi eksisting kawasan karst dilihat dari aspek bofisik dan masyarakat. Untuk tahapan analisis dan sintesis dilakukan penilaian terhadap potensi daya tarik pada kawasan karst untuk geowisata. Tahapan konsep dilakukan dengan mengembangkan ide berdasarkan hasil analisis dan sintesis. Sedangkan untuk tahap perencanaan merupakan pengembangan dari konsep yang menghasilkan rencana geowisata dan produk hasil berupa site plan.

\subsection{Penilaian Potensi Kawasan Karst untuk Geowisata}

Penilaian dilakukan untuk memilih dan menilai kelayakan suatu potensi untuk diangkat sebagai atraksi geowisata. Pendekatan dilakukan dengan memberikan nilai terhadap suatu daya tarik pada kawasan karst berdasarkan variabel pengembangan wisata, sumber daya alam, aspek sosial ekonomi, dan budaya, serta akseptibilitas masyarakat. Penilaian potensi daya tarik kawasan karst untuk geowisata diberi rentang nilai 2 - 8 untuk setiap variabel dengan nilai 2 (dua) adalah kategori sangat buruk, nilai 4 (empat) adalah kategori buruk, nilai 6 (enam) adalah kategori sedang dan nilai 8 (delapan) adalah kategori baik. Uraian penilaian potensi daya tarik kawasan karst untuk geowisata dapat dilihat pada Tabel 1.

Tabel 1. Variabel Penilaian Potensi Geowisata

\begin{tabular}{|c|c|c|c|c|c|}
\hline Variabel & Jenis & Baik (nilai 8) & $\begin{array}{l}\text { Sedang } \\
\text { (nilai 6) }\end{array}$ & Buruk (nilai 4) & $\begin{array}{l}\text { Sangat Buruk } \\
\text { (nilai 2) }\end{array}$ \\
\hline \multirow{9}{*}{$\begin{array}{c}\text { Aspek } \\
\text { Pengembangan } \\
\text { wisata }\end{array}$} & $\begin{array}{l}\text { Estetika } \\
\text { Keaslian }\end{array}$ & $\begin{array}{l}\text { Sangat indah } \\
\text { Asli }\end{array}$ & $\begin{array}{l}\text { Indah } \\
\text { ada campur tangan } \\
\text { manusia, bentuk asli }\end{array}$ & $\begin{array}{l}\text { Biasa } \\
\text { ada campur tangan } \\
\text { manusia, bentuk } \\
\text { baru }\end{array}$ & $\begin{array}{l}\text { Tidak indah } \\
\text { Sudah berubah }\end{array}$ \\
\hline & Keunikan & Sangat Unik & Unik & Biasa saja & Tidak unik \\
\hline & Kelangkaan & $\begin{array}{l}\text { Hanya terdapat } \\
\text { di tapak }\end{array}$ & $\begin{array}{l}\text { Terdapat <3 dilokasi } \\
\text { lain }\end{array}$ & $\begin{array}{l}\text { Terdapat 3-5 } \\
\text { dilokasi lain }\end{array}$ & $\begin{array}{l}\text { Terdapat }>5 \mathrm{di} \\
\text { lokasi lain }\end{array}$ \\
\hline & Kealamian & Masih alami & Kurang alami & Tidak alami & Rusak \\
\hline & Daya tahan & Sangat tahan & Tahan & Rentan & Sangat rentan \\
\hline & Fasilitas & $\begin{array}{l}\text { Tersedia, kondisi } \\
\text { baik }\end{array}$ & $\begin{array}{l}\text { Tersedia, kondisi } \\
\text { kurang baik }\end{array}$ & $\begin{array}{l}\text { Tersedia, kurang } \\
\text { lengkap }\end{array}$ & Tidak tersedia \\
\hline & $\begin{array}{l}\text { Transpotasi dan } \\
\text { aksesibilitas }\end{array}$ & $\begin{array}{l}\text { Jalan aspal, ada } \\
\text { kendaraan } \\
\text { umum }\end{array}$ & $\begin{array}{l}\text { Jalan aspal berbatu, } \\
\text { ada kendaraan umum }\end{array}$ & $\begin{array}{l}\text { Jalan aspal } \\
\text { berbatu, tanpa } \\
\text { kendaraan umum }\end{array}$ & $\begin{array}{l}\text { Jalan } \\
\text { berbatu/tanah, } \\
\text { tanpa kendaraan } \\
\text { umum }\end{array}$ \\
\hline & $\begin{array}{l}\text { Letak dari jalan } \\
\text { utama }\end{array}$ & $<1 \mathrm{~km}$ & $1-2 \mathrm{~km}$ & $2-3 \mathrm{~km}$ & $>3 \mathrm{~km}$ \\
\hline & Promosi & Sangat & Kurang & Tidak & Tidak tahu \\
\hline \multirow{3}{*}{$\begin{array}{l}\text { Aspek Kualitas } \\
\text { Sumberdaya Alam }\end{array}$} & $\begin{array}{l}\text { Sejarah yang } \\
\text { berkembang }\end{array}$ & $\begin{array}{l}\text { Ada, sangat } \\
\text { jelas }\end{array}$ & Ada, tidak jelas & Tidak ada & Tidak tahu \\
\hline & Fenomena alam & $\begin{array}{l}\text { Sangat } \\
\text { mencirikan }\end{array}$ & $\begin{array}{l}\text { Mencirikan, tidak } \\
\text { lengkap }\end{array}$ & kurang mencirikan & tidak mencirikan \\
\hline & Konservasi & $\begin{array}{l}\text { Sangat } \\
\text { dikonservasi }\end{array}$ & $\begin{array}{l}\text { Dikonservasi dengan } \\
\text { baik }\end{array}$ & $\begin{array}{l}\text { Kurang } \\
\text { dikonservasi }\end{array}$ & Rusak \\
\hline
\end{tabular}

Sumber: Modifikasi Damanik and Weber (2006), Gunn (1994), UNESCO (2001), Yusiana (2011) dan

Sampurno (1999). 
Lanjutan Tabel 1

\begin{tabular}{|c|c|c|c|c|c|}
\hline Variabel & Jenis & Baik (nilai 8) & $\begin{array}{l}\text { Sedang } \\
\text { (nilai 6) }\end{array}$ & Buruk (nilai 4) & $\begin{array}{l}\text { Sangat Buruk } \\
\text { (nilai 2) }\end{array}$ \\
\hline \multirow{6}{*}{$\begin{array}{c}\text { Aspek } \\
\text { Kualitas } \\
\text { Sumberdaya } \\
\text { Alam }\end{array}$} & Pemanfaatan & Sangat dimanfaatkan & Dimanfaatkan & Kurang & Dibiarkan saja \\
\hline & $\begin{array}{l}\text { Kerentanan } \\
\text { Vegetasi }\end{array}$ & $\begin{array}{l}\text { Tidak rentan, tidak } \\
\text { terancam }\end{array}$ & $\begin{array}{l}\text { Tidak rentan, } \\
\text { sebagai tanaman } \\
\text { pelindung }\end{array}$ & $\begin{array}{l}\text { Rentan, tidak } \\
\text { terancam }\end{array}$ & Rentan, terancam \\
\hline & Satwa Khusus & Ada, sangat dilindungi & $\begin{array}{l}\text { Ada, tidak } \\
\text { dilindungi }\end{array}$ & Tidak Ada & Tidak Tahu \\
\hline & Kondisi Hidrologi & $\begin{array}{l}\text { Ada, sumber mata air } \\
\text { parenial }\end{array}$ & $\begin{array}{l}\text { Ada, penangkap } \\
\text { air }\end{array}$ & $\begin{array}{l}\text { Ada, merupakan } \\
\text { aliran air }\end{array}$ & Tidak ada akuifer \\
\hline & Jenis Geologi & $\begin{array}{l}\text { Perkembangan } \\
\text { sempurna (Holokarst) }\end{array}$ & Karst transisi & $\begin{array}{l}\text { Perkembangan } \\
\text { parsial (Merokarst) }\end{array}$ & $\begin{array}{l}\text { Karst bersifat } \\
\text { lunak, butiran } \\
\text { pasir }\end{array}$ \\
\hline & Bentuk Topografi & Datar & $\begin{array}{l}\text { Landai, kemiringan } \\
8 \%\end{array}$ & $\begin{array}{l}\text { Landai, kemiringan } \\
8-15 \%\end{array}$ & $\begin{array}{l}\text { Landai, } \\
\text { kemiringan > } 15\end{array}$ \\
\hline \multirow{5}{*}{$\begin{array}{l}\text { Kondisi } \\
\text { sosial, } \\
\text { ekonomi dan } \\
\text { budaya }\end{array}$} & Pelestarian budaya & Sangat banyak & Cukup Banyak & Kurang & Tidak ada \\
\hline & Inovasi usaha lokal & Sangat banyak & Cukup Banyak & Kurang & Tidak ada \\
\hline & Kesempatan kerja & Sangat berpengaruh & $\begin{array}{l}\text { Cukup } \\
\text { berpengaruh }\end{array}$ & $\begin{array}{l}\text { Kurang } \\
\text { berpengaruh }\end{array}$ & $\begin{array}{l}\text { Tidak } \\
\text { berpengaruh }\end{array}$ \\
\hline & $\begin{array}{l}\text { Keamanan } \\
\text { lingkungan }\end{array}$ & Sangat aman & Cukup aman & Kurang aman & Bahaya \\
\hline & $\begin{array}{l}\text { Kepedulian terhadap } \\
\text { lingkungan }\end{array}$ & Sangat & Cukup & Kurang & Tidak peduli \\
\hline \multirow{5}{*}{$\begin{array}{l}\text { Akseptibilitas } \\
\text { Masyarakat }\end{array}$} & Pengembangan & Setuju & Kurang setuju & Tidak setuju & Tidak tahu \\
\hline & Pengelolaan & Setuju & Kurang setuju & Tidak setuju & Tidak tahu \\
\hline & $\begin{array}{l}\text { Peran aktif } \\
\text { masyarakat }\end{array}$ & $\mathrm{Ya}$ & Kurang & Tidak & Tidak tahu \\
\hline & $\begin{array}{l}\text { Keuntungan } \\
\text { kegiatan wisata }\end{array}$ & $\mathrm{Ya}$ & Kurang & Tidak & Tidak tahu \\
\hline & $\begin{array}{l}\text { Keberadaan } \\
\text { wisatawan }\end{array}$ & Bersedia & Kurang bersedia & Tidak bersedia & Tidak tahu \\
\hline
\end{tabular}

Total skor kemudian diklasifikasikan menggunakan interval kelas yang ditentukan dengan rumus Sturges (Thohar, 2015) sebagai berikut:

$$
\mathrm{K}=\frac{\mathrm{a}-\mathrm{b}}{\mathrm{u}}
$$

Keterangan:

$\mathrm{K}=$ Interval

$\mathrm{a}=$ Nilai skor tertinggi

$b=$ Nilai skor terendah

$\mathrm{u}=$ Jumlah kelas

Perhitungan interval kelas menggunakan penggabungan perhitungan antara skor maksimum potensi daya tarik dikurangi dengan penggabungan skor minimumnya. Sehingga akan diperoleh interval tersebut dibagi menjadi 4 (empat) klasifikasi dengan formula sebagai berikut :

$$
\begin{aligned}
& \mathrm{K}=\frac{(8 \times 30)-(2 \times 30)}{4} \\
& \mathrm{~K}=45
\end{aligned}
$$

Interval kelas potensi daya tarik kawasan karst untuk geowisata dari perhitungan di atas adalah

\begin{tabular}{|c|c|c|c|}
\hline No & Jumlah & Pembagian Kelas Potensial & Keterangan \\
\hline 1 & $195-240$ & Sangat sesuai (S4) & $\begin{array}{l}\text { Sebagian besar karakteristik daya tarik merupakan faktor pendorong } \\
\text { pengembangan wisata }\end{array}$ \\
\hline 2 & $150-194$ & Cukup sesuai (S3) & $\begin{array}{l}\text { Sebagian karakteristik daya tarik merupakan faktor pendorong } \\
\text { pengembangan wisata dan faktor penghambat yang seimbang }\end{array}$ \\
\hline 3 & $105-149$ & Kurang sesuai (S2) & $\begin{array}{l}\text { Sebagian kecil karakteristik daya tarik merupakan faktor pendorong } \\
\text { dan memiliki faktor kendala }\end{array}$ \\
\hline 4 & $60-104$ & Tidak sesuai (S1) & $\begin{array}{l}\text { Karakterisik daya tarik tidak merupakan faktor pendorong } \\
\text { pengembangan wisata. }\end{array}$ \\
\hline
\end{tabular}
sebagai berikut :

Tabel 2. Interval Kelas Potensial Daya Tarik Geowisata 


\subsection{Perencanaan Kawasan Geowisata}

Rencana lanskap geowisata merupakan rencana lanjutan untuk mendapatkan tatanan lanskap pendukung kawasan geowisata karst berdasarkan hasil penilaian daya tarik. Rencana mengacu pada tahapan proses perancangan lengkap Simonds (1983) yaitu ruang, aktivitas dan fasilitas. Produk akhir yang dihasilkan yaitu berupa site plan tapak untuk kawasan geowisata.

\section{Hasil dan Pembahasan}

\subsection{Gambaran umum Kawasan Karst Kabupaten Grobogan}

Kawasan karst Kabupaten Grobogan terletak pada bagian utara Kabupaten Grobogan, Jawa Tengah yang merupakan bagian wilayah Pegunungan Kendeng Utara dan bagian dari Kawasan Bentang Alam Karst Sukolilo (KBAK Sukolilo). Kawasan Bentang Alam Karst Sukolilo sendiri telah ditetapkan sebagai kawasan lindung geologi berdasarkan Keputusan Menteri Energi Sumberdaya dan Mineral No 2641 Tahun 2014. Kawasan karst di Kabupaten Grobogan memiliki total luas secara keseluruhan yaitu 112,20 km$^{2}$ dengan ketinggian 50-500 mdpl. Kondisi topografi di kawasan karst adalah landai sampai curam dengan jenis tanah mediteran dan latosol.

Kawasan karst di Kabupaten Grobogan memiliki struktur geologi perlipatan dan persesaran yang disusun oleh batu gamping. Batu gamping yang menyusun kawasan karst berfungsi sebagai akuifer lapisan bawah tanah yang mengandung air dan dapat mengalirkan air. Air pada akuifer batu gamping tersimpan pada rekahan tanah dan lubang-lubang, bahkan saluran-saluran gua serta sungai bawah tanah. Kawasan karst di Kabupaten Grobogan memiliki jenis flora yang mendominasi yaitu Jati (Tectona grandis), sedangkan jenis fauna yang mencirikan kawasan karst yaitu kelelawar.

Kawasan karst di Kabupaten Grobogan merupakan kawasan yang berada di pedesaan dan jauh dari kota. Aksesibilitas menuju kawasan ini relatif mudah,, walaupun kondisi jalan di kawasan karst berbukit dan curam. Waktu tempuh dari pusat kota menuju kawasan karst $\pm 20-50$ menit. Sirkulasi yang ada di kawasan karst Kabupaten Grobogan merupakan jalan desa berupa jalan beton di samping kanan-kiri dan bebatuan dengan lebar $\pm 3-5$ meter. Masyarakat yang tinggal di kawasan karst adalah termasuk masyarakat pedalaman yang berprofesi sebagai petani. Karakteristik masyarakat lebih mengutamakan harmoni dengan hakikat hidup terikat pada tradisi dan ritual.

\subsection{Identifikasi Potensi Wisata Kawasan Karst}

Identifikasi potensi dan karakkteristik dari kawasan karst yang dapat dijadikan sebagai daya tarik terdapat 12 yang dapat dilihat pada Tabel 3 dan gambar peta persebaran pada Gambar 2.

Tabel 3. Potensi Daya Tarik Wisata di Kawasan Karst Kabupaten Grobogan

\begin{tabular}{lll}
\hline No & \multicolumn{1}{c}{ Nama Daya Tarik } & \multicolumn{1}{c}{ Lokasi } \\
\hline 1 & Gua Macan dan Gua lawa & Desa Sedayu Kecamatan Grobogan \\
2 & Air Terjun Gulingan & Desa Sedayu Kecamatan Grobogan \\
3 & Bukit Lamping & Desa Jati Pohon Kecamatan Grobogan \\
4 & Air Terjun Widuri & Desa Kemadoh Batur Kec. Tawangharjo \\
5 & Air Terjun Nganyongan & Desa Karangasem Kecamatan Wirosari \\
6 & Puncak Pelangi Gunung Ulo & Desa Dokoro Kec. Wirosari \\
7 & Watu Ondo & Desa Lebak, Kec. Grobogan \\
8 & Air Terjun Bengkat & Desa Taruman Kec. Klambu \\
9 & Grojogan Jati Anom & Desa Sumber Jatipohon Kec. Grobogan \\
10 & Grojogan Kinasih & Desa Karangasem, Kec. Wirosari \\
11 & Sendang Wangi & Desa Sumberagung, Kec. Ngaringan \\
12 & Sendang Keongan & Desa Penganten, Kec. Klambu \\
\hline
\end{tabular}

Sumber: Data Lapang 


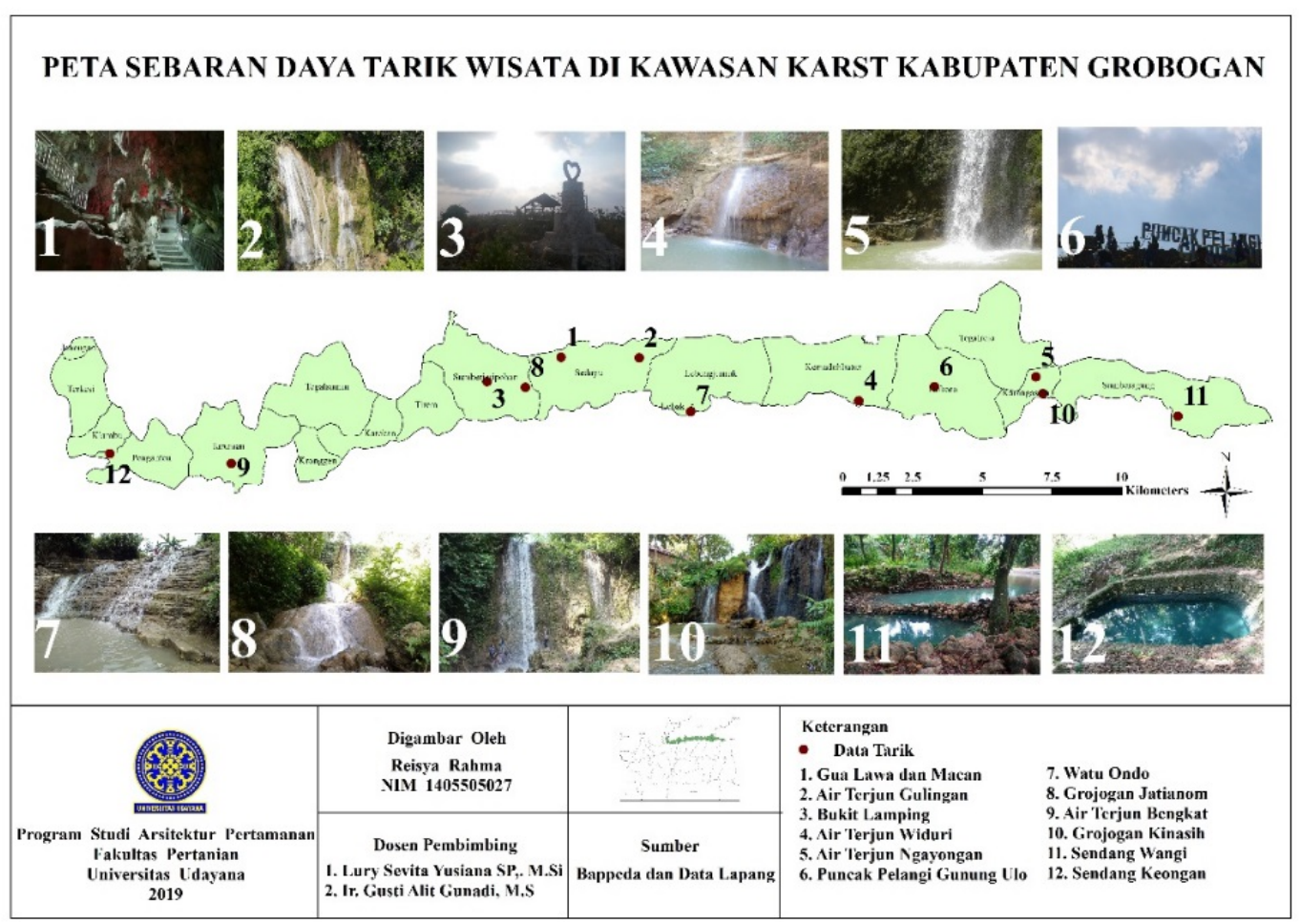

Gambar 2. Potensi Wisata Kawasan Karst Kabupaten Grobogan

\subsection{Analisis Tapak}

Kawasan karst memiliki dampak besar terhadap kerusakan jika kawasan tersebut tidak dikelola dengan baik. Hilangnya satu bukit dapat mengakibatkan hilangnya fungsi hidrologis kawasan. Selain itu, kondisi tanah memiliki kemiringan 8-15\% dengan struktur batu gamping masif yang bersifat kasar dan keras serta batu gamping kapuran yang bersifat lunak dan rapuh sehingga memiliki resiko rawan terjadinya longsor.

Pada kawasan karst juga terdapat flora dan fauna endemik yang berstatus terancam punah. Jika terdapat perubahan pada lingkungan sekitarnya akan berdampak pada ekosistemnya, sehingga pemanfaatan dan pengelolaan pada kawasan karst di Kabupaten Grobogan yang dilakukan tidak berpotensi menganggu proses karstifikasi, merusak bentuk-bentuk karst serta ataupun merusak fungsi kawasan.

\subsection{Penilaian Potensi Geowisata}

\subsubsection{Kualitas Sumberdaya Alam}

Hasil penilaian kualitas sumberdaya alam pada daya tarik kawasan karst untuk geowisata di Kabupaten Grobogan dijabarkan dalam bentuk tabel yang dapat dilihat pada Tabel 4.

Tabel 4 Penilaian Kualitas Sumberdaya Alam

\begin{tabular}{|c|c|c|c|c|c|c|c|c|c|c|c|c|}
\hline & Parameter & $\begin{array}{l}\mathscr{\infty} \\
\frac{\mathbb{D}}{2} . \\
\stackrel{5}{5}\end{array}$ & 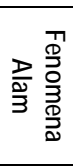 & 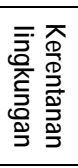 & 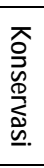 & 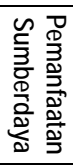 & 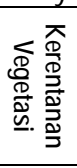 & 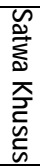 & $\begin{array}{l}\text { 포․ } \\
\text { 을 } \\
\text { 응 } \\
\text { 으․ }\end{array}$ & 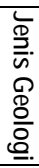 & $\begin{array}{l}\text { 공 } \\
\text { 응 } \\
\stackrel{3}{9}\end{array}$ & $\begin{array}{l}\text { 엄 } \\
\text { 몽 } \\
\text { 응 }\end{array}$ \\
\hline \multicolumn{2}{|c|}{ Potensi Wisata } & $\mathrm{N}$ & $\mathbf{N}$ & $\mathrm{N}$ & $\mathbf{N}$ & $\mathrm{N}$ & $\mathrm{N}$ & $\mathbf{N}$ & $\mathbf{N}$ & $\mathbf{N}$ & $\mathrm{N}$ & $\mathrm{S}$ \\
\hline 1. & Gua Lawa dan Macan & 6 & 8 & 2 & 8 & 8 & 2 & 8 & 8 & 8 & 2 & 60 \\
\hline 2. & Air Terjun Gulingan & 2 & 8 & 2 & 8 & 8 & 2 & 8 & 8 & 8 & 2 & 56 \\
\hline 3. & Bukit Lamping & 6 & 6 & 2 & 8 & 8 & 2 & 8 & 6 & 6 & 2 & 54 \\
\hline 4. & Air Terjun Widuri & 6 & 6 & 2 & 8 & 8 & 2 & 8 & 8 & 2 & 6 & 56 \\
\hline 5. & Air Terjun Nganyongan & 2 & 6 & 2 & 8 & 8 & 2 & 8 & 8 & 2 & 2 & 48 \\
\hline 6. & Puncak Pelangi Gunung Ulo & 2 & 6 & 2 & 6 & 6 & 2 & 8 & 6 & 6 & 2 & 44 \\
\hline 7. & Watu Ondo & 2 & 6 & 2 & 8 & 4 & 2 & 8 & 8 & 2 & 2 & 46 \\
\hline 8. & Grojogan Jati Anom & 2 & 6 & 2 & 8 & 2 & 2 & 8 & 8 & 2 & 2 & 42 \\
\hline 9. & Air Terjun Bengkat & 2 & 6 & 2 & 8 & 4 & 2 & 8 & 8 & 2 & 6 & 48 \\
\hline 10. & Grojogan Kinasih & 2 & 6 & 2 & 8 & 4 & 2 & 8 & 8 & 2 & 2 & 44 \\
\hline 11. & Sendang Wangi & 2 & 6 & 2 & 6 & 2 & 2 & 8 & 8 & 2 & 8 & 46 \\
\hline 12. & Sendang Keongan & 2 & 6 & 2 & 6 & 2 & 2 & 8 & 8 & 2 & 8 & 46 \\
\hline
\end{tabular}

Sumber: Olahan data lapang ; Keterangan: $\mathrm{N}=$ Nilai, S = Skor, Nilai ( 8 = baik, 6 = sedang , 4 = buruk, 2 = sangat buruk) 
Hasil tabel penilaian menunjukkan bahwa 12 daya tarik merupakan sumberdaya alam yang memiliki kondisi lingkungan yang perlu diperhatikan dalam pengembangan dan pengelolaannya.

\subsubsection{Pengembangan Wisata}

Hasil penilaian pengembangan wisata pada daya tarik kawasan karst untuk geowisata di Kabupaten Grobogan dijabarkan dalam bentuk tabel yang dapat dilihat pada Tabel 5 .

Tabel 5. Penilaian Pengembangan Wisata

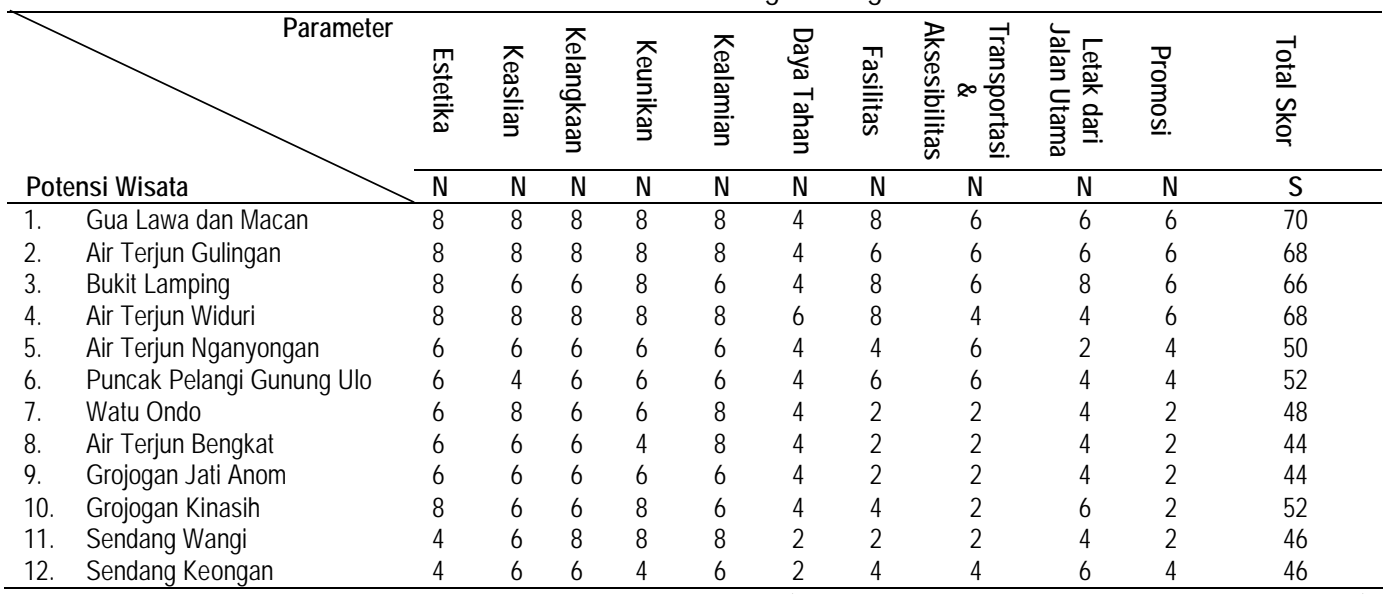

Sumber: Olahan data lapang ; Keterangan: N = Nilai, S = Skor, Nilai (8 = baik, 6 = sedang , 4 = buruk, 2 = sangat buruk)

Hasil tabel penilaian menunjukkan bahwa 12 daya tarik di kawasan karst Kabupaten Grobogan memiliki potensi sebagai tempat wisata, tetapi dalam pengembangannya beberapa daya tarik masih rendah.

3.4.3 Kondisi Sosial, Ekonomi, dan Budaya Masyarakat

Hasil penilaian kondisi sosial, ekonomi dan budaya masyarakat pada daya tarik kawasan karst untuk geowisata di Kabupaten Grobogan dijabarkan dalam bentuk tabel yang dapat dilihat pada Tabel 6 .

Tabel 6. Penilaian Kondisi Sosial, Ekonomi, dan Budaya Masyarakat

\begin{tabular}{|c|c|c|c|c|c|c|}
\hline Parameter & $\begin{array}{c}\text { Pelestarian } \\
\text { Budaya }\end{array}$ & $\begin{array}{c}\text { Inovasi } \\
\text { Usaha Lokal }\end{array}$ & $\begin{array}{l}\text { Kesempatan } \\
\text { Kerja }\end{array}$ & $\begin{array}{l}\text { Keamanan } \\
\text { Lingkungan }\end{array}$ & $\begin{array}{l}\text { Kepedulian } \\
\text { Lingkungan }\end{array}$ & $\begin{array}{l}\text { Total } \\
\text { Skor }\end{array}$ \\
\hline Potensi Wisata & $\mathrm{N}$ & $\mathrm{N}$ & $\mathrm{N}$ & $\mathrm{N}$ & $\mathrm{N}$ & $\mathbf{S}$ \\
\hline 1. Gua Lawa dan Macan & 6 & 8 & 8 & 8 & 8 & 38 \\
\hline 2. Air Terjun Gulingan & 6 & 6 & 8 & 8 & 8 & 36 \\
\hline 3. Bukit Lamping & 6 & 8 & 8 & 8 & 8 & 38 \\
\hline 4. Air Terjun Widuri & 6 & 8 & 8 & 8 & 8 & 38 \\
\hline 5. Air Terjun Nganyongan & 4 & 6 & 4 & 6 & 8 & 28 \\
\hline 6. Puncak Pelangi Gunung Ulo & 4 & 6 & 6 & 6 & 6 & 28 \\
\hline 7. Watu Ondo & 2 & 2 & 2 & 6 & 6 & 18 \\
\hline 8. Air Terjun Bengkat & 2 & 2 & 2 & 6 & 6 & 18 \\
\hline 9. Grojogan Jati Anom & 2 & 2 & 2 & 6 & 8 & 20 \\
\hline 10. Grojogan Kinasih & 4 & 4 & 4 & 6 & 6 & 24 \\
\hline 11. Sendang Wangi & 2 & 2 & 2 & 6 & 6 & 18 \\
\hline 12. Sendang Keongan & 2 & 4 & 4 & 6 & 6 & 22 \\
\hline
\end{tabular}

Hasil tabel penilaian menunjukkan bahwa dari 12 daya tarik di kawasan karst Kabupaten Grobogan hanya 4 (empat) daya tarik yang memiliki nilai tinggi yairu Gua Lawa dan Macan, Air Terjun Gulingan, Bukit Lamping dan Air Terjun Widuri. Berdasarkan hasil analisis, daya tarik lainnya yang memiliki nilai rendah masih dibutuhkan pengembangannya untuk kegiatan wisata.

\subsubsection{Akseptibilitas Masayarakat}

Hasil penilaian akseptibilitas masyarakat pada daya tarik kawasan karst untuk geowisata di Kabupaten Grobogan dijabarkan dalam bentuk tabel yang dapat dilihat pada Tabel 7. 
Tabel 7. Penilaian Akseptibilitas Masyarakat

\begin{tabular}{|c|c|c|c|c|c|c|}
\hline Parameter & Pengembangan & Pengelolaan & $\begin{array}{c}\text { Peran } \\
\text { Aktif }\end{array}$ & Keuntungan & $\begin{array}{c}\text { Keberadaan } \\
\text { Wisatawan }\end{array}$ & Total Skor \\
\hline Potensi Wisata & $\mathrm{N}$ & $\mathrm{N}$ & $\mathrm{N}$ & $\mathbf{N}$ & $\mathrm{N}$ & $\mathrm{S}$ \\
\hline 1. Gua Lawa dan Macan & 8 & 8 & 6 & 6 & 8 & 36 \\
\hline 2. Air Terjun Gulingan & 8 & 8 & 6 & 6 & 8 & 36 \\
\hline 3. Bukit Lamping & 8 & 8 & 6 & 8 & 8 & 38 \\
\hline 4. Air Terjun Widuri & 8 & 6 & 6 & 8 & 8 & 36 \\
\hline 5. $\quad$ Air Terjun Nganyongan & 6 & 6 & 4 & 4 & 6 & 26 \\
\hline 6. $\quad$ Puncak Pelangi Gunung Ulo & 6 & 6 & 4 & 6 & 6 & 28 \\
\hline 7. Watu Ondo & 4 & 4 & 4 & 4 & 2 & 18 \\
\hline 8. $\quad$ Air Terjun Bengkat & 4 & 4 & 4 & 4 & 2 & 18 \\
\hline 9. Grojogan Jati Anom & 2 & 2 & 4 & 2 & 2 & 12 \\
\hline 10. Grojogan Kinasih & 4 & 4 & 4 & 4 & 6 & 22 \\
\hline 11. Sendang Wangi & 2 & 2 & 2 & 2 & 4 & 12 \\
\hline 12. Sendang Keongan & 4 & 4 & 4 & 4 & 6 & 22 \\
\hline
\end{tabular}

Sumber: Olahan data lapang; Keterangan: $\mathrm{N}=$ Nilai, $\mathrm{S}=$ Skor, Nilai $(8=$ baik, 6 = sedang , 4 = buruk, 2 = sangat buruk)

Hasil tabel penilaian menunjukkan bahwa sebagian daya tarik di kawasan karst Kabupaten Grobogan, partisipasi masyarakat dalam kegiatan wisata masih pasif atau belum berperan aktif.

\subsubsection{Kesesuaian Daya Tarik}

Hasil dari penilaian kemudian diperoleh kesesuaian daya tarik untuk geowisata berdasarkan interval kelas potensial. Berikut adalah hasil skor gabungan dari penilaian daya tarik kawasan karst untuk geowisata yang dapat dilihat pada Tabel 8.

Tabel 8. Hasil Skor Gabungan Penilaian Potensi Daya Tarik Kawasan Karst

\begin{tabular}{|c|c|c|c|c|c|c|}
\hline Variabel & 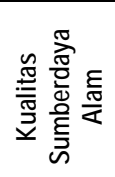 & 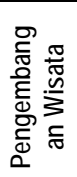 & 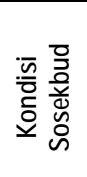 & 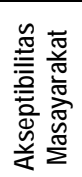 & $\frac{\frac{\pi}{\frac{\pi}{E}}}{5}$ & Kelas Potensial \\
\hline Potensi Wisata & $\mathrm{S}$ & $\mathrm{S}$ & $\mathbf{S}$ & $\mathbf{S}$ & $\mathbf{S}$ & \\
\hline 1. Gua Lawa dan Macan & 60 & 70 & 38 & 36 & 204 & Sangat Sesuai (S4) \\
\hline Air Terjun Gulingan & 56 & 68 & 36 & 36 & 196 & Sangat Sesuai (S4) \\
\hline Bukit Lamping & 54 & 66 & 38 & 38 & 196 & Sangat Sesuai (S4) \\
\hline Air Terjun Widuri & 56 & 68 & 38 & 36 & 198 & Sangat Sesuai (S4) \\
\hline Air Terjun Nganyongan & 48 & 50 & 28 & 26 & 152 & Cukup Sesuai (S3) \\
\hline Puncak Pelangi Gunung Ulo & 44 & 52 & 28 & 28 & 152 & Cukup Sesuai (S3) \\
\hline Watu Ondo & 46 & 48 & 18 & 18 & 130 & Kurang Sesuai (S2) \\
\hline Air Terjun Bengkat & 42 & 44 & 18 & 18 & 122 & Kurang Sesuai (S2) \\
\hline Grojogan Jati Anom & 48 & 44 & 20 & 12 & 124 & Kurang Sesuai (S2) \\
\hline 10. Grojogan Kinasih & 44 & 52 & 24 & 22 & 142 & Kurang Sesuai (S2) \\
\hline 11. Sendang Wangi & 46 & 46 & 18 & 12 & 122 & Kurang Sesuai (S2) \\
\hline 12. Sendang Keongan & 46 & 46 & 22 & 22 & 136 & Kurang Sesuai (S2) \\
\hline
\end{tabular}

Keterangan: S (Skor), sangat sesuai ( 195-240), cukup sesuai (150-194), kurang sesuai (105-149), tidak sesuai (60-104)

Berdasarkan hasil penilaian maka perencanaan kawasan karst untuk geowisata di Kabupaten Grobogan, dilakukan pada daya tarik yang termasuk kategori sangat sesuai (S4). Hasil yang diperoleh memnunjukkan bahwa daya tarik Gua Lawa dan Macan, Air Terjun Widuri, Bukit Lamping dan Air Terjun Gulingan potensial untuk dijadikan kawasan geowisata. Dari aspek sumberdaya alam memiliki fenomena alam yang mencirikan kawasan karst dengan topografi yang berbukit. Aspek pengembangan wisata berpotensi sebagai wisata minat khusus. Aspek kondisi sosial, ekonomi dan budaya menunjukkan kegiatan wisata pada daya tarik tidak menganggu dan tidak bertentangan dengan masyarakat di sekitarnya. Sedangkan dari aspek akseptibilitas masyarakat menunjukkan masyarakat menerima apabila ke 4 (empat) daya tarik dikembangankan sebagai kawasan geowisata dan masyarakat akan berperan aktif didalamnya. 


\subsection{Konsep}

Perencanaan kawasan karst di Kabupaten Grobogan didasarkan pada konsep geowisata sebagai wisata minat khusus. Geowisata menawarkan konsep wisata alam yang menonjolkan keindahan, keunikan, kelangkaan, dan keajaiban suatu fenomena alam yang berkaitan erat dengan gejala-gejala geologi.

\subsection{Pengembangan Konsep}

Konsep geowisata yang dikembangkan menghasilkan konsep ruang, konsep aktivitas dan konsep fasilitas

a. Konsep ruang dibagi menjadi 3 (tiga), yaitu ruang penerimaan, ruang inti wisata, dan ruang penyangga.

b. Konsep aktivitas, direncanakan dengan memberikan batasan terhadap, aktivitas pengunjung sesuai dengan daya dukung lingkungan. Selain itu juga direncanakan dapat memberi tambahan pengetahuan, pengalaman, dan informasi bagi para pengunjung serta memberikan peluang usaha bagi masyarakat lokal

c. Konsep fasilitas, konsep fasilitas yang direncanakan berupa fasilitas yang menunjang dan mendukung aktivitas wisata serta fasilitas yang dikembangkan tidak boleh mengganggu dan merusak kondisi eksisting.

\subsection{Perencanaan}

Pengembangan geowisata meliputi daya tarik dan atraksi wisata Gua Lawa dan Macan, Air Terjun Gulingan, Bukit Lamping dan Air Terjun Widuri dengan luas kawasan yaitu $\pm 45,15 \mathrm{~km}^{2}$

\subsubsection{Rencana Tata Ruang}

Zonasi pada kawasan geowisata karst terbagi atas 4 (empat) ruang yang terdiri dari ruang penerimaan, ruang inti wisata, dan ruang penyangga. Pembagian rencana tata ruang dapat dilihat pada gambar blok plan (Gambar 3).

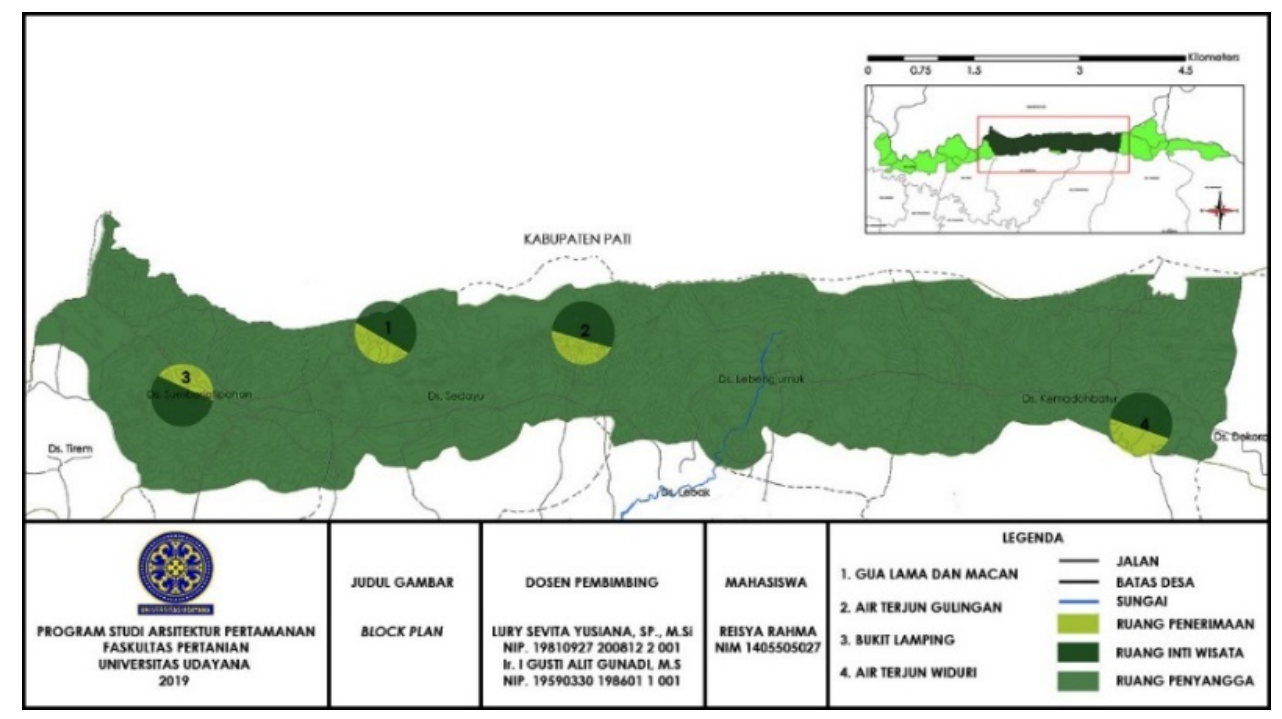

\subsubsection{Rencana Aktivitas}

Gambar 3. Block Plan

Aktivitas yang direncanakan berdasarkan penggunaan tapak terkait rencana ruang. Ruang penerimaan merupakan awal pengunjung masuk ke dalam daya tarik kawasan geowisata dan aktivitas hanya berupa keluar masuk pada daya tarik kawasan geowisata. Ruang inti wisata merupakan pusat aktivitas wisata. Ruang inti wisata terbagi menjadi 2 (dua) yaitu ruang pelayanan dan ruang wisata. Aktivitas yang direncanakan pada ruang pelayanan yaitu aktivitas pembelian tiket masuk, parkir kendaraan dan mencari informasi. Aktivitas ruang wisata yang direncanakan adalah aktivitas yang bersifat aktif dan pasif, dimana pengunjung diberikan batasan tertentu dalam melakukan kegiatan wisatanya demi menjaga keselamatan pengunjung dan mencegah terjadinya kerusakan lingkungan. Aktivitas yang dilakukan pada 
ruang penyangga disarankan bersifat pasif karena bertujuan untuk melindungi ekosistem yang ada pada kawasan karst.

\subsubsection{Rencana Fasilitas}

Fasilitas disesuaikan dengan kebutuhan dan keberadaan atraksi wisata yang ada serta daya dukung lingkungan. Fasilitas yang dihadirkan seminimal mungkin sehingga tidak mengubah ekosistem sebelumnya. Penyediaan fasilitas lebih dianjurkan berupa fasilitas keamanan dan keselamatan.

Uraian rencana aktivitas dan fasilitas dapat dilihat pada Tabel 9. Gambar site plan masing-masing daya tarik pada kawasan geowisata karst di Kabupaten Grobogan dapat dilihat pada Gambar 4 (a,b,c).

Tabel 9. Rencana Aktivitas, Fasilitas dan Ilustrasi

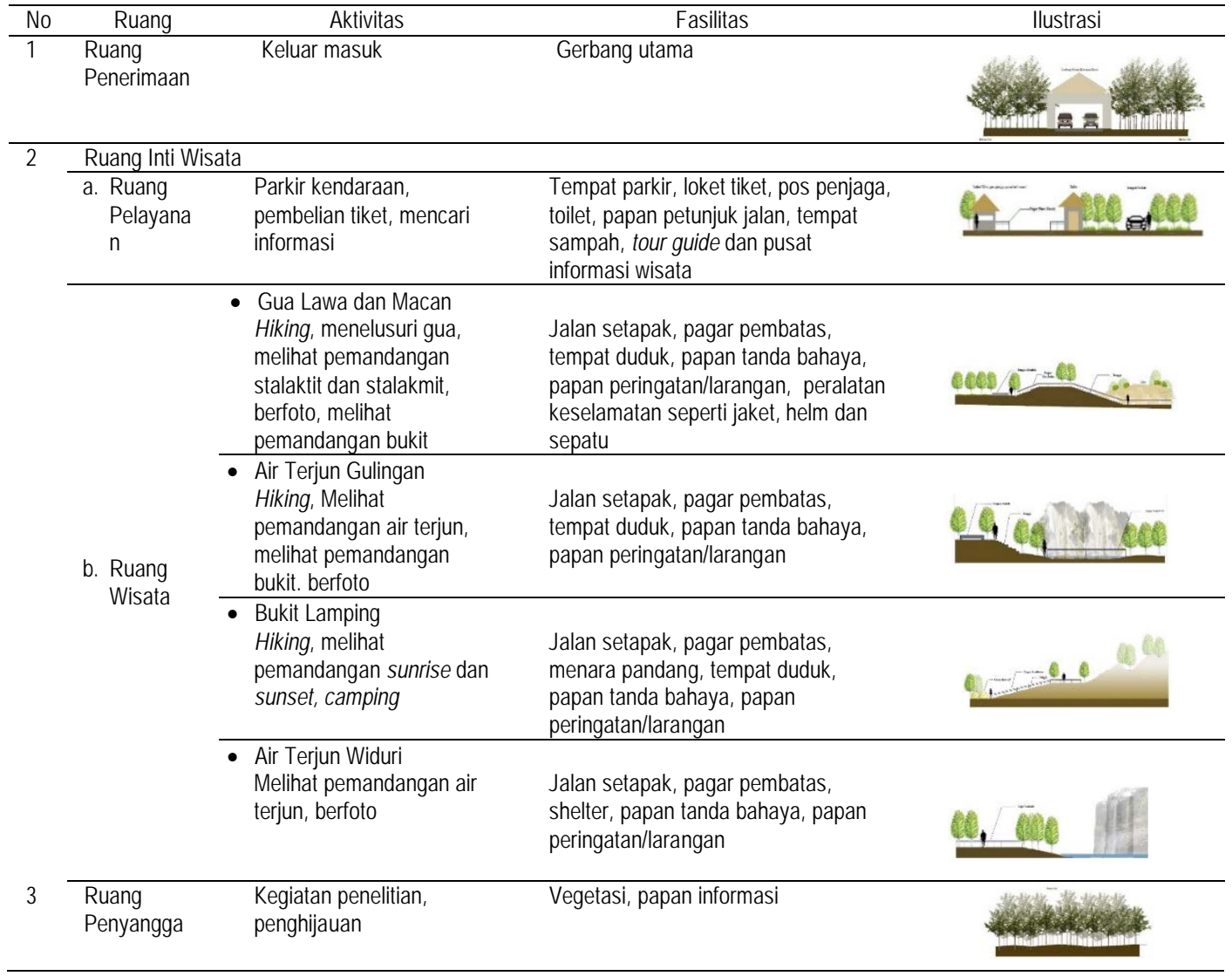




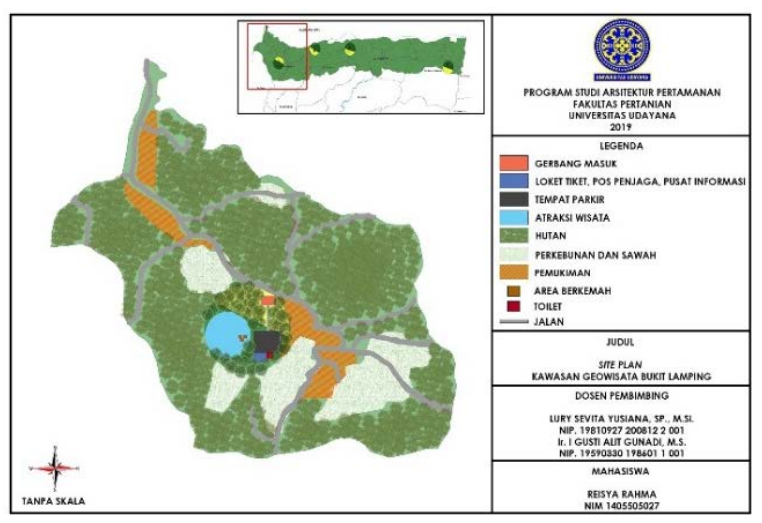

a. Site Plan Kawasan Geowisata Bukit Lamping

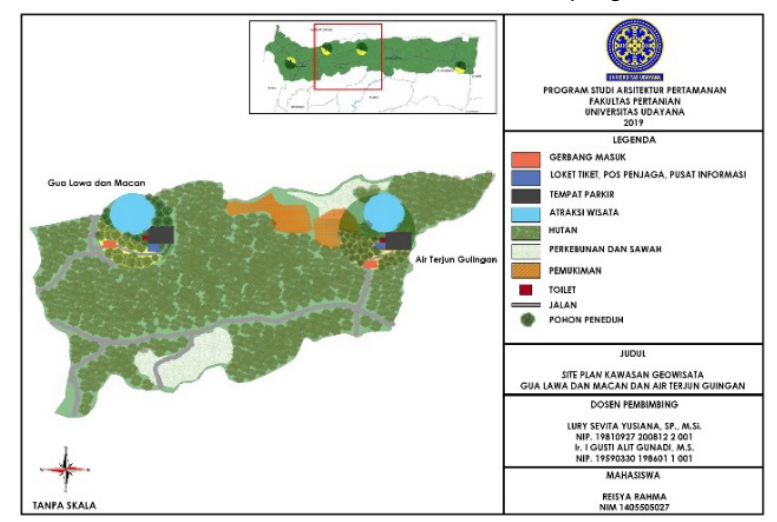

b. Site Plan Kawasan Geowisata Gua Lawa dan Macan dan Air Terjun Gulingan

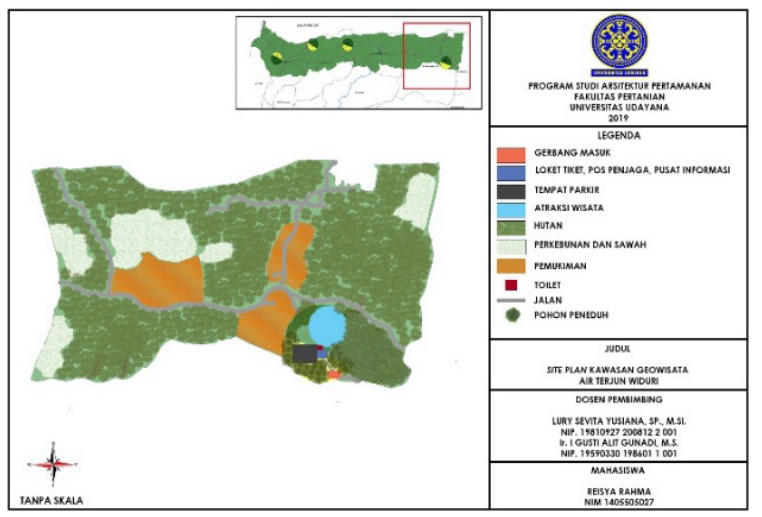

c. Site Plan Kawasan Geowisata Air Terjun Widuri

Gambar 4. Site Plan Daya Tarik pada Kawasan Geowisata Karst di Kabupaten Grobogan

\section{Simpulan}

Berdasarkan 12 daya tarik yang tersebar pada kawasan karst di Kabupaten Grobogan, terdapat 4 (empat) daya tarik yang memiliki potensi tinggi untuk dikembangkan sebagai daya tarik geowisata yaitu Gua Lawa dan Macan, Air Terjun Gulingan, Bukit Lamping, dan Air Terjun Widuri. Konsep dasar dari perencanaan kawasan karst adalah konsep geowisata sebagai wisata minat khusus. Perencanaan geowisata terbagi menjadi 3 (tiga) yaitu rencana tata ruang, rencana aktivitas dan rencana fasilitas. Bentuk aktivitas yang dilakukan berupa aktivitas rekreatif edukatif yang didasarkan pada minat khusus wisatawan seperti hiking, tracking, camping, refreshing, telusur gua, melihat pemandangan, berfoto, ataupun kegiatan penelitian. Sedangkan fasilitas yang dihadirkan seminimal mungkin tidak mengubah ekosistem pada kawasan karst. 


\section{Daftar Pustaka}

Badan Lingkungan Hidup. (2014). Mewujudkan Tata Kelola Kawasan Hutan dan Karst Kabupaten Grobogan yang Berkelanjutan dan Memberdayakan Masyarakat. Diakses dari https://www.academia.edu/8949434/Mewujudkan_Tata_Kelola_Kawasan_Hutan_dan_Karst_Kabupa ten_Grobogan_Yang_Berkelanjutan_dan_Memberdayakan_Masyarakat.

Damanik, J. dan Weber, H. F. (2006). Perencanaan Ekowisata dari Teori ke Aplikasi. Yogyakarta: Andi Offset.

Gunn, C. A. (1994). Tourism Planning Basics, Concepts, Cases. Third Edition. London: Tylor \& Francis.

Kementerian Energi dan Sumber Daya Mineral. (2012). Peraturan Menteri Energi Sumber Daya Mineral No 17 Tahun 2012 tentang Penetapan Bentang Alam Kawasan Karst. Menteri Energi dan Sumber Daya Mineral. Diakses dari https://jdih. esdm.go.id/peraturan/Permen\%20ESDM\%2017\%202012.pdf.

Kementerian Energi dan Sumber Daya Alam. (2014). Keputusan Menteri Energi Sumber Daya Mineral No 2641 Tahun 2014 Tentang Penetapan Kawasan Kawasan Karst Sukolilo. Diakses dari http://tataruangpertanahan.com/regulasi/pdf/kepmen/menesdm/Kepmen-esdm-2641-2014.pdf.

Simonds, J. O. (1983). Landscape Architecture: A Manual Site Planning and Design. McGraw-Hill Book Co. Inc. New York: McGraw-Hill Book Co. Inc.

Thohar, G. B. (2015). Analisis Potensi Obyek Wisata Umbul Ngrancah di Desa Udanwuh Kecamatan Kaliwungu Kabupaten Semarang. Diakses dari http://eprints. ums.ac.id/35984/7/NASKAH\%20PUBLIKASI.pdf

UNESCO. (2001). The Recommendation on Geologycal Herritage Promotion. Available online at: http://www.unesco.org/science/earthsciences/geological_herritage.html

Yusiana, L. S., S. Nurisjah dan D. Soedharma. (2011). Perencanaan Lanskap Wisata Pesisir Berkelanjutan di Teluk Konga, Flores Timur, Nusa Tenggara Timur. E-Jurnal Lanskap Indonesia, 3(2), 66-72. 